\title{
The emergence of subaerial crust and onset of weathering 3.7 billion years ago
}

Desiree Roerdink ( $\square$ Desiree.Roerdink@uib.no)

University of Bergen https://orcid.org/0000-0002-1182-3606

\section{Yuval Ronen}

University of Bergen

\section{Harald Strauss}

University of Muenster

\section{Paul Mason}

Utrecht University

\section{Article}

Keywords:

Posted Date: November 10th, 2020

DOl: https://doi.org/10.21203/rs.3.rs-98804/v1

License: (9) This work is licensed under a Creative Commons Attribution 4.0 International License. Read Full License 


\section{Abstract}

Reconstructing the emergence and weathering of continental crust in the Archean is crucial for our understanding of early ocean chemistry, biosphere evolution and the onset of plate tectonics. However, considerable disagreement exists between the elemental and isotopic proxies that have been used to trace crustal input into marine sediments and data are scarce prior to 3 billion years ago. Here we show that chemical weathering modified the Sr isotopic composition of seawater as recorded in 3.52-3.20 Ga stratiform barite deposits from three different cratons. Using a combination of $\mathrm{Sr}, \mathrm{S}$ and $\mathrm{O}$ isotope data, barite petrography and a hydrothermal mixing model, we calculate a novel $\mathrm{Sr}$ isotope evolution trend for Paleoarchean seawater that is much more radiogenic than the curve previously determined from carbonate rocks. Our findings require the presence and weathering of subaerial and evolved (high $\mathrm{Rb} / \mathrm{Sr}$ ) crust from $3.7 \pm 0.1 \mathrm{Ga}$ onwards. This Eoarchean onset of crustal weathering affected the chemistry of the oceans and supplied nutrients to the marine biosphere 500 million years earlier than previously thought.

\section{Background}

One of the most accurate and complete records for tracing the weathering of continental crust over geological time are strontium isotopes $\left({ }^{87} \mathrm{Sr} /{ }^{86} \mathrm{Sr}\right)$ in marine chemical sediments. Strontium in seawater is derived from two sources with distinct radiogenic isotopic compositions: hydrothermal alteration of oceanic crust with low and mantle-like ${ }^{87} \mathrm{Sr} /{ }^{86} \mathrm{Sr}$, and subaerial weathering of continental crust with higher ${ }^{87} \mathrm{Sr} /{ }^{86} \mathrm{Sr}{ }^{1}$. Because $\mathrm{Sr}$ has a long residence time relative to the ocean mixing rate, ${ }^{87} \mathrm{Sr} /{ }^{86} \mathrm{Sr}$ in seawater is globally homogenized and the balance between oceanic and continental inputs can be recorded in the $\mathrm{Sr}$ isotope ratios of authigenic marine minerals. Typically the lowest ${ }^{87} \mathrm{Sr} /{ }^{86} \mathrm{Sr}$ (least radiogenic) are taken as the best estimate of seawater at any time since post-depositional alteration is most likely to increase $\mathrm{Sr}$ isotope ratios ${ }^{2}$. Throughout the Phanerozoic, carbonate shells and limestones show many secular variations in seawater ${ }^{87} \mathrm{Sr} /{ }^{86} \mathrm{Sr}$ that can be linked to changes in seafloor spreading rates, as well as shifting tectonic, geographic and climatic controls on the Sr isotopic composition of riverine runoff ${ }^{3}$. Further back in time, the seawater $\mathrm{Sr}$ isotope record becomes compromised by the scarcity of unaltered sedimentary carbonate rocks. Sparse Archean carbonates with highly unradiogenic ${ }^{87} \mathrm{Sr} /{ }^{86} \mathrm{Sr}$ have therefore been interpreted to represent seawater, suggesting a mantle-dominated ocean chemistry at this time ${ }^{4,5,6}$. This curve and the concomitant rise in seawater ${ }^{87} \mathrm{Sr} /{ }^{86} \mathrm{Sr}$ at the ArcheanProterozoic boundary supports models and proxies that argue for the late emergence of continental crust and onset of weathering around $2.5 \mathrm{Ga} 7,8,9,10,11,12,13$. However, recent work on two barite deposits suggested much higher seawater ${ }^{87} \mathrm{Sr} /{ }^{86} \mathrm{Sr}$ than the mantle-like value assumed from the Archean carbonate record at $3.2 \mathrm{Ga}^{14,15}$. This finding questions the assumption that the unradiogenic carbonates truly reflect seawater, and challenges the validity of a mantle-like Sr isotope seawater evolution curve for the Paleoarchean. The earlier onset of weathering inferred from these barite data would be consistent with $\mathrm{Ti}$ isotopic evidence for emerged felsic crust at $3.5 \mathrm{Ga}{ }^{16}$, weathering-induced decoupling of $\mathrm{Hf}$ and 
Nd isotope systems in $3.4 \mathrm{Ga}$ chert ${ }^{17}$, and $\mathrm{Hf}$ isotope ratios in black shales indicating weathering of evolved crust by $3.0 \mathrm{Ga}^{18}$.

To correctly reconstruct the onset of crustal weathering and emergence of continental crust, here we investigate the $\mathrm{Sr}, \mathrm{S}$ and $\mathrm{O}$ isotopic compositions of six stratiform marine-hydrothermal barite deposits from three different cratons covering a time window of 320 million years. Using a mixing model to assess hydrothermal influence on the barite ${ }^{87} \mathrm{Sr} /{ }^{86} \mathrm{Sr}$, we calculate a new $\mathrm{Sr}$ isotope evolution trend for Paleoarchean seawater and use this result to constrain the timing at which weathering began to modify early ocean chemistry.

\section{Does barite reflect seawater?}

We studied field and drill core samples from barite deposits at Londozi (3.52 Ga, Theespruit Fm), Vergelegen (3.41 Ga, Kromberg Fm), Stentor/Amo (3.26 Ga, Bien Venue Fm) and Barite Valley (3.24 Ga, Middle Mapepe Fm) in the Kaapvaal craton, North Pole (3.49 Ga, Dresser Fm) in the Pilbara craton and Sargur (3.20 Ga, Sargur Group) in the Dharwar craton (Table S1). All barite deposits occur in volcanicsedimentary successions consistent with shallow to deep marine environments $19,20,21,22,23,24,25$. Multiple sulfur isotope data provide evidence for atmospherically-derived sulfate in the barites from a well-mixed global seawater reservoir $26,27,28$ or local felsic volcanic eruptions ${ }^{29,30}$. In contrast, field observations suggest a hydrothermal origin for the barium ${ }^{25}$. In all localities, barite is strongly associated with chert ${ }^{21}$, silica dykes feed into barite horizons at Barite Valley and North Pole ${ }^{25,31}$, and barium-rich hydrothermal alteration zones with Ba-feldspar underlie barite at Londozi and Sargur ${ }^{19,29}$. However, all deposits lack polymetallic sulfide deposits, indicating that hydrothermal fluid temperatures were relatively low and likely below $150^{\circ} \mathrm{C}^{32}$. Low-temperature hydrothermal activity is also consistent with the lack of an underlying magmatic system, absence of sintering and the small vertical extent of chert dykes at Barite Valley ${ }^{25}$.

Two types of barite are observed in the six deposits: bladed barite consisting of course blades up to several centimeters long, and fine-grained granular barite (Fig. S1). Crystal morphology alone does not reveal the origin of the barite. However, a combination of sedimentological evidence and morphology supports a primary origin for bladed barite at Barite Valley, except for some isolated blades cutting through barite sands that appear to have grown diagenetically 23,25 . A primary origin for bladed barite is consistent with the well-formed, tabular to bladed crystal morphology that is predicted to grow in settings with low to moderate degrees of barite oversaturation ${ }^{33}$ and is found in modern hydrothermal settings ${ }^{34}$. In contrast, granular barite is often found in association with heavy minerals and reworked quartz, indicating a detrital origin for this morphological type ${ }^{23,25}$. Equigranular textures can also form by recrystallization of barite during diagenesis or metamorphism that has affected all deposits ${ }^{35}$, from lower greenschist facies $\left(300-400^{\circ} \mathrm{C}\right)$ at North Pole, Barite Valley and Vergelegen ${ }^{36,37}$ to upper greenschist facies $\left(400-500^{\circ} \mathrm{C}\right)$ at Stentor/Amo ${ }^{20}$ and amphibolite facies $\left(500-650^{\circ} \mathrm{C}\right)$ at Londozi and 
Sargur ${ }^{38,39}$. In order to determine which barite can be used to constrain Paleoarchean seawater ${ }^{87} \mathrm{Sr} /{ }^{86} \mathrm{Sr}$, field data and mineral morphology must therefore be integrated with geochemical proxies.

Within individual deposits, bladed barite samples are $\mathrm{Sr}$ isotopically distinct from granular barite. Measured ${ }^{87} \mathrm{Sr} /{ }^{86} \mathrm{Sr}$ values are lowest in bladed barite (Fig. 1a), with weighted averages $( \pm 95 \%$ confidence intervals) ranging from $0.700562 \pm 0.00015$ at Londozi $(n=2), 0.700841 \pm 0.00004$ at Vergelegen $(n=6), 0.701295 \pm 0.00008$ at Barite Valley $(n=4)$ to 0.701333 at Sargur (Table S2). No bladed barite was found in samples from the Stentor/Amo deposit. In contrast, granular barite is characterized by higher average ${ }^{87} \mathrm{Sr} /{ }^{86} \mathrm{Sr}$ values of $0.700757 \pm 0.00010$ at Londozi $(n=21), 0.701112 \pm$ 0.00001 at Vergelegen $(n=2), 0.701240 \pm 0.00013$ at Stentor/Amo $(n=5), 0.701478$ at Barite Valley and $0.701814 \pm 0.00033$ at Sargur $(n=3)$. These higher values cannot be explained by in situ ${ }^{87} \mathrm{Rb}$ decay, because measured $\mathrm{Rb}$ concentrations in acid-leached fractions from both types of barite are very low and would require corrections less than our analytical precision (Table S3). In addition, we carefully selected least weathered samples to avoid contamination with high ${ }^{87} \mathrm{Sr} /{ }^{86} \mathrm{Sr}$ phases, as exemplified by the two highly weathered samples from Barite Valley (Fig. 1a).

Unlike the marine carbonate record, the lowest ${ }^{87} \mathrm{Sr} /{ }^{86} \mathrm{Sr}$ values in bladed barite cannot be unambiguously interpreted to reflect seawater as ratios may have been lowered by hydrothermal input of unradiogenic $\mathrm{Sr}^{15}$. We therefore combine ${ }^{87} \mathrm{Sr} /{ }^{86} \mathrm{Sr}$ data with oxygen and sulfur isotopic compositions to select which barite is most representative of seawater (Fig. 1b-d) 27,40 . Bladed and granular barite is characterized by $\delta^{18} \mathrm{O}$ and $\delta^{34} S$ values that fall within the range reported for Paleoarchean seawater sulfate from sulfate minerals and carbonate-associated sulfate (Fig. 1b, 1c) 15, 26, 41, 42 . Seawater-like $\delta^{18} \mathrm{O}$ and $\delta^{34} \mathrm{~S}$ values do not give direct evidence for seawater $\mathrm{Sr}$ isotope ratios in hydrothermal barite, since the source of $\mathrm{Sr}$ is not directly coupled to that of $\mathrm{SO}_{4}{ }^{2-35}$. However, the observation above is consistent with the low-temperature hydrothermal settings inferred from field data, as modification of seawater-like $\delta^{18} \mathrm{O}$ values is expected above $150^{\circ} \mathrm{C}$ due to rapid oxygen isotope exchange between dissolved sulfate and water ${ }^{43}$. This in turn suggests that measured ${ }^{87} \mathrm{Sr} /{ }^{86} \mathrm{Sr}$ have been relatively little affected by Sr from a non-seawater source, because leaching of Sr from rocks is limited at these low temperatures and low- to intermediate-temperature hydrothermal fluids are dominated by seawaterderived $\mathrm{Sr}^{44,45}$.

Importantly, we observe the highest $\delta^{18} 0$ values for each deposit in bladed barite and in association with the most negative, and therefore most seawater-like ${ }^{46}$, anomalous sulfur isotope signatures $\left(D^{33} S\right.$, see Methods for calculation, Table S2). These samples also display a strong positive correlation $\left(R^{2}=0.95\right)$ between ${ }^{87} \mathrm{Sr} /{ }^{86} \mathrm{Sr}$ and $\Delta^{33} \mathrm{~S}$ (Fig. $1 \mathrm{~d}$ ), in contrast to a weaker correlation for granular barite $\left(R^{2}=0.64\right.$, not shown in Fig. 1d). Previous work has demonstrated that the magnitude of seawater sulfate $D^{33} S$ decreases throughout the Paleoarchean, as shown in Fig. 1d 26, 27, 42. The observed correlation between $\mathrm{Sr}$ and $\mathrm{S}$ isotopes in bladed barite is therefore best explained by co-evolution of $D^{33} \mathrm{~S}$ and ${ }^{87} \mathrm{Sr} /{ }^{86} \mathrm{Sr}$ in seawater due to progressive decay of ${ }^{87} \mathrm{Rb}$. In contrast, this correlation may have been blurred in the 
granular barite as a result of alteration or contamination, which is consistent with granular textures resulting from recrystallization processes. At water-rock ratios of 1 to 10 , metamorphic fluids with 50$1000 \mathrm{ppm} \mathrm{Sr}$ and ${ }^{87} \mathrm{Sr} /{ }^{86} \mathrm{Sr} \sim 0.703-0.706$ can shift Sr isotopic compositions from those measured in the bladed barite towards the higher values in granular barite samples (Fig. S2).

Based on the $\mathrm{O}, \mathrm{S}$ and $\mathrm{Sr}$ isotope systematics outlined above, we conclude that ${ }^{87} \mathrm{Sr} /{ }^{86} \mathrm{Sr}$ of bladed barite is as close to Paleoarchean seawater as possible for a hydrothermal deposit. The ${ }^{87} \mathrm{Sr} /{ }^{86} \mathrm{Sr}$ values in the bladed barite samples define a strong regression line (Fig. $2, R^{2}=0.98$ ), and are more radiogenic than the Paleoarchean primitive mantle (Fig. 1a) calculated from the Basaltic Achondrite Best Initial (BABI) at 4.56 $\mathrm{Ga}$ of ${ }^{87} \mathrm{Sr} /{ }^{86} \mathrm{Sr}=0.69897{ }^{47}$ and bulk Earth ${ }^{87} \mathrm{Rb} /{ }^{86} \mathrm{Sr}=0.085^{48}$. Values also plot above estimates of the depleted mantle based on ${ }^{87} \mathrm{Sr} /{ }^{86} \mathrm{Sr}=0.703$ for modern mid-ocean ridge basalt ${ }^{49}$ and an initial value of ${ }^{87} \mathrm{Sr} /{ }^{86} \mathrm{Sr}=0.69950(\mathrm{DM} 1)^{9}$ or $0.69897(\mathrm{DM} 2)^{47}$ (Fig. 1a). Our findings are consistent with previously reported Sr isotopic compositions of the Barite Valley, Sargur, Vergelegen and North Pole deposits ${ }^{14,15}$, ${ }^{50}$. To go further, we explore next the hydrothermal influence on barite ${ }^{87} \mathrm{Sr} /{ }^{86} \mathrm{Sr}$ values to assess the $\mathrm{Sr}$ isotopic composition of the Paleoarchean oceans.

\section{Paleoarchean seawater evolution trend}

We use a hydrothermal mixing model to calculate a plausible seawater Sr evolution trend from the ${ }^{87} \mathrm{Sr} /{ }^{86} \mathrm{Sr}$ values measured in bladed barite samples, based on the low-temperature hydrothermal setting inferred from field and oxygen isotope data. In our model (see Methods), we calculate mixing ratios of seawater $\left(20^{\circ} \mathrm{C}, 0.6 \mathrm{M} \mathrm{NaCl}\right.$ salinity) ${ }^{51,52}$ and hydrothermal fluid $\left(150^{\circ} \mathrm{C}\right)$ that lead to oversaturation with respect to barite ${ }^{53}$. We use a local seawater sulfate concentration of $8 \mu \mathrm{M}$ based on observed $12-20 \%$ o differences between barite and pyrite $\delta^{34} S^{54,55}$, and assume the same $\mathrm{SO}_{4}{ }^{2-}$ concentration for the hydrothermal fluid as anhydrite precipitation and thermochemical sulfate reduction were likely negligible at $150^{\circ} \mathrm{C}$. Our calculations for a range of Ba concentrations show that the highest degree of oversaturation occurs for a mixture consisting of $10-40 \%$ hydrothermal fluid (Table S5). Calculated saturation indices are low $(<0.2)$, which is consistent with our interpretation above that bladed barite formed as primary crystals ${ }^{33}$.

We use this result and a two-component mixing model ${ }^{34}$ to calculate ${ }^{87} \mathrm{Sr} /{ }^{86} \mathrm{Sr}$ values of seawaterhydrothermal fluid mixtures from which barite precipitated. By varying the input value for seawater ${ }^{87} \mathrm{Sr} /{ }^{86} \mathrm{Sr}$, we assess which seawater composition is feasible with the highest and lowest ${ }^{87} \mathrm{Sr} /{ }^{86} \mathrm{Sr}$ values measured in bladed barite from Londozi, Vergelegen and Barite Valley. To constrain the Sr isotopic composition of the hydrothermal fluids, we assume that $\mathrm{Sr}$ is predominantly derived from seawater (80\%) with a small contribution from leached crust $(20 \%)$, as observed in low-temperature $\left(150^{\circ} \mathrm{C}\right)$ hydrothermal experiments ${ }^{45}$ and modern low-intermediate temperature hydrothermal fluids ${ }^{44}$, and consistent with seawater-dominated REE patterns in Paleoarchean alteration zones ${ }^{32}$. For each deposit, we explore ${ }^{87} \mathrm{Sr} /{ }^{86} \mathrm{Sr}$ variations during hydrothermal leaching of mafic and felsic rocks, represented by $\mathrm{Sr}$ isotope evolution curves for the depleted mantle and continental crust, respectively. 
From our constraints on the chemical conditions required for barite precipitation and comparison of theoretical seawater-hydrothermal mixtures with those recorded in the bladed barite, we obtain a seawater $\mathrm{Sr}$ isotope evolution trend with a slope corresponding to ${ }^{87} \mathrm{Rb} /{ }^{86} \mathrm{Sr}$ values of $0.194-0.198$ (Fig. 2). Sr isotopic compositions of single bladed barite samples from North Pole and Sargur fall well within the predicted trend, as well as granular barite from the Stentor deposit. Calculated ${ }^{87} \mathrm{Rb} /{ }^{86} \mathrm{Sr}$ values are substantially higher than the estimated value for the early Archean depleted mantle $(0.07 \pm 0.007){ }^{50}$ and contrast strongly with the mantle-dominated curve inferred from carbonate ${ }^{87} \mathrm{Sr} /{ }^{86} \mathrm{Sr}{ }^{4,5,6}$ (Fig. 3). Our results empirically constrain the seawater $\mathrm{Sr}$ isotope evolution trend significantly further back in time compared to the curve predicted from the extrapolation of $3.2 \mathrm{Ga}$ barite ${ }^{87} \mathrm{Sr} /{ }^{86} \mathrm{Sr}{ }^{15}, 56$ (Fig. 3).

\section{Onset of subaerial crustal weathering}

The radiogenic Sr isotope values for 3.52-3.20 Ga Paleoarchean seawater imply detectable weathering of an emerged and felsic crustal source at least 300 million years further back in time than what has previously been reported at $3.2 \mathrm{Ga}^{15}$. We further advance this by constraining the start of subaerial weathering from the intersection of our seawater evolution trend and mantle curves, which represents the time at which the input of crustal $\mathrm{Sr}$ started to modify the ${ }^{87} \mathrm{Sr} /{ }^{86} \mathrm{Sr}$ of seawater away from mantledominated values. Our calculated trend for Paleoarchean seawater ${ }^{87} \mathrm{Sr} /{ }^{86} \mathrm{Sr}$ indicates an onset at approximately $3.7 \pm 0.1 \mathrm{Ga}$ based on the intersection with the primitive mantle curve, $3.6 \pm 0.1 \mathrm{Ga}$ from depleted mantle curve DM1 and 3.8 $\pm 0.1 \mathrm{Ga}$ from depleted mantle curve DM2 (Fig. 2). Improved constraints on the Paleoarchean $\mathrm{Sr}$ isotope mantle curve are required to further reduce the uncertainty on this estimate. However, the late Eoarchean onset of crustal weathering observed from chemical signatures is consistent with the siliciclastic rock record which shows that physical weathering products appear for the first time in greenstone belts around $3.4 \mathrm{Ga}^{57}$ and possibly as early as $3.7 \mathrm{Ga}{ }^{58}$ (Fig. 3), as well as examples of exposed land surfaces by $3.5 \mathrm{Ga}^{59}$ and evidence for the existence of felsic crust at this time ${ }^{60}$. Our findings indicate that weathering substantially modified the $\mathrm{Sr}$ isotope budget of Paleoarchean seawater, in contrast to its oxygen isotope composition that was recently shown to be unaffected by this ${ }^{12}$.

Comparison of our Sr isotope data and revised seawater trend with other records of weathering (e.g. ${ }^{6,11}$, ${ }^{61}$ ) highlights the scarcity of data in the Paleoarchean and the importance of the barite record for this period in Earth's history. Paleoarchean carbonate from the Pilbara and Kaapvaal craton ${ }^{1,5}$ displays significantly more radiogenic ${ }^{87} \mathrm{Sr} /{ }^{86} \mathrm{Sr}$ than barite (Fig. 3), reflecting the higher preservation potential of insoluble barite during diagenesis and metamorphism ${ }^{35}$. The combined updated barite (blue lines in Fig. 3) and carbonate ${ }^{56}$ (green line in Fig. 3) ${ }^{87} \mathrm{Sr} /{ }^{86} \mathrm{Sr}$ record for the Archean shows little secular variation from 3.7 to $2.5 \mathrm{Ga}$, which differs from the recently predicted sharp rise in seawater ${ }^{87} \mathrm{Sr} /{ }^{86} \mathrm{Sr}$ at $3.2 \mathrm{Ga}{ }^{56}$. The absence of strong secular variations in the Archean ${ }^{87} \mathrm{Sr} /{ }^{86} \mathrm{Sr}$ record may be partially explained by the low temporal resolution of the data compared to the Phanerozoic, although a linear Sr isotope trend in the Paleoarchean is consistent with small ${ }^{87} \mathrm{Sr} /{ }^{86} \mathrm{Sr}$ variations in newly formed crust due to little time for 
radiogenic ingrowth of ${ }^{87} \mathrm{Sr}$. It also tentatively suggests no measurable long-term shifts in tectonic, geographic and climatic controls on seawater ${ }^{87} \mathrm{Sr} /{ }^{86} \mathrm{Sr}$ throughout the Archean, in contrast to the changes observed in carbonate ${ }^{87} \mathrm{Sr} /{ }^{86} \mathrm{Sr}$ from the Proterozoic and Mesozoic into the Cenozoic ${ }^{62}$.

If the extrapolation of our seawater Sr isotope trend is correct, it implies that the late Eoarchean geodynamic regime generated granitic magmas and sufficient continental freeboard to support weathering of emerged felsic crust from $3.7 \mathrm{Ga}$. The globally significant changes in seawater ${ }^{87} \mathrm{Sr} /{ }^{86} \mathrm{Sr}$ defined by our samples from three different cratons suggest that subaerial weathering was a relatively widespread phenomenon, likely requiring a larger relative area of emerged crust than the $4 \%$ previously reported for the Neoarchean (see Supplementary Information) ${ }^{63}$. Following the same reasoning as above, the absence of radiogenic Sr in seawater before $3.7 \mathrm{Ga}$ suggests that prior to this time the extent of felsic landmass and subaerial weathering was very limited. This in turn would have hampered the colonization of land, inhibited the supply of nutrients to the oceans ${ }^{64}$ and restricted the extent of epicontinental seas in the early Eoarchean, possibly limiting the evolution of photosynthetically fueled ecosystems. The lack of undisputed evidence for microbial activity in supracrustal rocks older than 3.5 Ga may reflect such an Eoarchean planet with fewer favorable environments for life to flourish than in the Paleoarchean, when crustal emergence and weathering facilitated life in shallow marine settings.

\section{Methods}

\section{Analytical}

Barite powders were drilled from the same spots as used for multiple sulfur isotope analysis ${ }^{27}$ using a diamond microdrill. Circa $100 \mathrm{mg}$ of pure barite was reacted with concentrated $\mathrm{HF}$ to form insoluble $\mathrm{SrF}_{2}$, which was centrifuged together with undissolved $\mathrm{BaSO}_{4}$ to remove the supernatant. Strontium was subsequently leached from the residual solids with $2 \mathrm{~N} \mathrm{HNO}_{3}$ under sub-boiling conditions for 2 days. The dissolved fraction was purified on an Eichrom $\mathrm{Sr}$ Spec ion exchange resin and analyzed for Sr isotopes using a Finnigan MAT 262 Thermal Ionization Mass Spectrometer at the University of Bergen. Values are normalized relative to ${ }^{87} \mathrm{Sr} /{ }^{86} \mathrm{Sr}=0.710240$ for standard SRM987, with an error $(2 \sigma)$ of 0.000009 . Aliquots of the supernatant after the HF dissolution step and the dissolved fraction after the $2 \mathrm{~N} \mathrm{HNO}_{3}$ dissolution step were analyzed for $\mathrm{Rb}$ and $\mathrm{Sr}$ concentrations using a ThermoScientific Element XR inductively-coupled plasma mass spectrometer at the University of Bergen.

Oxygen isotopes were measured in a selection of barite powders from Londozi, Vergelegen and Stentor/Amo using a ThermoFinnigan TC/EA high-temperature pyrolysis unit coupled to a ThermoQuest Delta Plus XL mass spectrometer at the University of Münster ${ }^{40}$. Results are reported relative to Vienna Standard Mean Ocean Water (V-SMOW) with an average analytical precision of $0.19 \%$ on $\delta^{18} \mathrm{O}$. In addition, multiple sulfur isotopes were measured in samples from Sargur after converting barite into sulfide by boiling with a Thode reduction solution (concentrated $\mathrm{HCl}, \mathrm{HI}$ and $\mathrm{H}_{3} \mathrm{PO}_{2}$ ). Isotope analyses were performed at the University of Maryland on a dual-inlet ThermoFinnigan MAT 253 following 
cryogenic and gas chromatographic purification, with an average external precision of $0.1 \%$ on $\delta^{34} S$ and $0.02 \%$ on $D^{33} S$ (reported relative to $V-C D T$ ) ${ }^{27}$. Values of $D^{33} S$ are calculated as $D^{33} S=\delta^{33} S-$ $1000\left[\left(1+\delta^{34} S / 1000\right)^{0.515}-1\right]$.

\section{Model}

Barite solubility products at $0.6 \mathrm{M} \mathrm{NaCl}$ (modern seawater salinity) were approximated by linear extrapolation of experimental results at $0.2 \mathrm{M} \mathrm{NaCl}$ and $1 \mathrm{M} \mathrm{NaCl}$ and $25-250^{\circ} \mathrm{C}^{53}$. The temperature of the hydrothermal fluid was estimated at $150^{\circ} \mathrm{C}$ based on element enrichment patterns and oxygen isotopes in similar silica alteration zones ${ }^{32}$, and seawater temperature was estimated at $20^{\circ} \mathrm{C}$ based on isotopic evidence for modern-like temperatures ${ }^{51}$. Sulfate concentrations were constrained from the model of Crowe et al. ${ }^{54}$ for sulfate-dependent microbial isotope effects and measured differences in $\delta^{34} \mathrm{~S}$ of 12 $20 \%$ o between barite and associated biogenic pyrite minerals ${ }^{55}$. The saturation index SI was calculated as $\log \mathrm{Q} / \mathrm{K}_{\mathrm{sp}}$ with $\mathrm{Q}=\left[\mathrm{Ba}^{2+}\right]\left[\mathrm{SO}_{4}{ }^{2-}\right]$ for different mixtures of hydrothermal fluid and seawater, assuming mixing temperatures without conductive cooling and $\mathrm{Ba}$ concentrations in the hydrothermal fluid and seawater at $75 \%, 90 \%$ and $99 \%$ of the solubility concentrations at $150^{\circ} \mathrm{C}$ and $20^{\circ} \mathrm{C}$, respectively (Table S5).

Based on the obtained mixing ratio of hydrothermal fluid (HF) and seawater (SW) during barite precipitation, barite (BA) Sr isotopic compositions were predicted using the following equation modified from Jamieson et al. ${ }^{34}$ :

$$
{ }^{87} \mathrm{Sr} /{ }^{86} \mathrm{Sr}_{\mathrm{BA}}=\frac{{ }^{87} \mathrm{Sr} /{ }^{86} \mathrm{Sr}_{\mathrm{SW}}-\left({ }^{87} \mathrm{Sr} /{ }^{86} \mathrm{Sr}_{\mathrm{SW}} \times \% \mathrm{HF}\right)+\left(\frac{[\mathrm{Sr}]_{\mathrm{HF}}}{[\mathrm{Sr}]_{\mathrm{SW}}} \times{ }^{87} \mathrm{Sr} /{ }^{86} \mathrm{Sr}_{\mathrm{HF}} \times \% \mathrm{HF}\right)}{\left(1+\left(\% \mathrm{HF} \times \frac{[\mathrm{Sr}]_{\mathrm{HF}}}{[\mathrm{Sr}]_{\mathrm{SW}}}\right)-\% \mathrm{HF}\right)}
$$

with \%HF as the fraction of hydrothermal fluid in the mixture during barite precipitation (0.1 to 0.4$)$ and $[\mathrm{Sr}]_{\mathrm{HF}} /[\mathrm{Sr}]_{\mathrm{SW}}$ as the ratio of Sr concentrations in the hydrothermal fluid versus seawater. Results were calculated for $[\mathrm{Sr}]_{\mathrm{HF}} /[\mathrm{Sr}]_{\mathrm{SW}}$ ratios of $0.5,1,2$ and 3 based on enrichment factors observed in modern seafloor hydrothermal fluids ${ }^{35}$. Sr isotopic compositions of hydrothermal fluids were calculated as:

$$
{ }^{87} \mathrm{Sr} /{ }^{86} \mathrm{Sr}_{\mathrm{HF}}=0.8 \times{ }^{87} \mathrm{Sr} /{ }^{86} \mathrm{Sr}_{S W}+0.2 \times{ }^{87} \mathrm{Sr} /{ }^{86} \mathrm{Sr}_{L}
$$

with ${ }^{87} \mathrm{Sr} /{ }^{86} \mathrm{Sr}_{\mathrm{L}}$ as the isotopic composition of $\mathrm{Sr}$ leached from host rocks and fractions of seawater and rock-derived $\mathrm{Sr}$ based on experimental results at $150^{\circ} \mathrm{C}^{45}$. Barite $\mathrm{Sr}$ isotopic compositions were 
calculated for two end-member scenarios: (1) leaching of mafic rocks, with ${ }^{87} \mathrm{Sr} /{ }^{86} \mathrm{Sr}_{\mathrm{L}}$ obtained from linearly extrapolating BABI $(0.69897)^{47}$ to the average modern mid-ocean ridge basalt value of 0.703 (DM2) at the age of each deposit, and (2) leaching of felsic rocks, with ${ }^{87} \mathrm{Sr} /{ }^{86} \mathrm{Sr}_{\mathrm{L}}$ constrained by linearly extrapolating $\mathrm{BABI}$ to the average modern crust value of $0.7119^{9}$. Calculations were iterated for different input values of ${ }^{87} \mathrm{Sr} /{ }^{86} \mathrm{Sr}_{\mathrm{SW}}$ to obtain the highest and lowest possible seawater $\mathrm{Sr}$ isotope composition that can explain the range in ${ }^{87} \mathrm{Sr} /{ }^{86} \mathrm{Sr}$ measured in bladed barite samples. No calculations were performed for Stentor/Amo and Sargur due to insufficient bladed barite samples.

\section{Declarations}

\section{Acknowledgements}

We thank Axel Hoffman for samples from the Sargur barite, Siv Hjorth Dundas for ICP-MS analyses, and Joost Hoek, James Farquhar and the University of Maryland stable isotope laboratory for multiple sulfur isotope analyses. Cedric Hamelin and Helen King are thanked for discussions, and Andreas Beinlich, Douwe van Hinsbergen, Hari Tsikos and Mark van Zuilen are thanked for critically reading through an earlier version of the manuscript and providing constructive comments. Aaron Satkoski and two anonymous reviewers are thanked for providing valuable comments that have improved the manuscript significantly. This research was funded by the Research Council of Norway through the Centre for Geobiology and fieldwork in South Africa was supported by the Stichting Dr Schurmannfonds.

\section{Author contributions}

D.R. conceived the study, D.R. and P.M. provided and prepared samples, Y.R. and H.S. measured data, D.R. and P.M. interpreted data and wrote the manuscript.

\section{Data availability}

Strontium isotope data obtained in this study is available in Supplementary Table S2 and the Pangaea data repository under doi.pangaea.de/10.1594/PANGAEA.913541. We have used published strontium isotope data for Barite Valley, Sargur and North Pole barite samples from ${ }^{14,15,50}$, sulfur isotope data for Londozi, North Pole, Vergelegen, Stentor/Amo and Barite Valley from ${ }^{27}$ and oxygen isotope data for Barite Valley from ${ }^{40}$. Ages of the barite deposits are from ${ }^{19}, 21,23,27,29,31$. Sr isotope data for Archean carbonate samples were obtained from ${ }^{56,65}$.

\section{Competing interests}

The authors declare no competing interests.

\section{References}


1. Veizer J. Strontium isotopes in seawater through time. Annual Review of Earth and Planetary Sciences 1989, 17(1): 141-167.

2. Veizer J, Compston W. ${ }^{87} \mathrm{Sr} /{ }^{86} \mathrm{Sr}$ composition of seawater during the Phanerozoic. Geochim Cosmochim Acta 1974, 38(9): 1461-1484.

3. Burke W, Denison R, Hetherington E, Koepnick R, Nelson H, Otto J. Variation of seawater $87 \mathrm{Sr} / 86 \mathrm{Sr}$ throughout Phanerozoic time. Geology 1982, 10(10): 516-519.

4. Veizer J, Compston W. ${ }^{87} \mathrm{Sr} /{ }^{86} \mathrm{Sr}$ in Precambrian carbonates as an index of crustal evolution. Geochim Cosmochim Acta 1976, 40(8): 905-914.

5. Veizer J, Hoefs J, Lowe D, Thurston P. Geochemistry of Precambrian carbonates: II. Archean greenstone belts and Archean sea water. Geochim Cosmochim Acta 1989, 53(4): 859-871.

6. Shields G, Veizer J. Precambrian marine carbonate isotope database: Version 1.1. Geochem Geophys Geosyst 2002, 3(6): 1 of 12-12 of 12.

7. Bindeman I, Zakharov D, Palandri J, Greber ND, Dauphas N, Retallack G, et al. Rapid emergence of subaerial landmasses and onset of a modern hydrologic cycle 2.5 billion years ago. Nature 2018, 557(7706): 545.

8. Kamber BS. Archean mafic-ultramafic volcanic landmasses and their effect on ocean-atmosphere chemistry. Chem Geol 2010, 274(1-2): 19-28.

9. Kamber BS, Webb GE. The geochemistry of late Archaean microbial carbonate: implications for ocean chemistry and continental erosion history. Geochim Cosmochim Acta 2001, 65(15): 25092525.

10. Flament N, Coltice N, Rey PF. A case for late-Archaean continental emergence from thermal evolution models and hypsometry. Earth Planet Sci Lett 2008, 275(3-4): 326-336.

11. Pons ML, Fujii T, Rosing M, Quitté G, Télouk P, Albarède F. A Zn isotope perspective on the rise of continents. Geobiology 2013, 11(3): 201-214.

12. Johnson BW, Wing BA. Limited Archaean continental emergence reflected in an early Archaean $180-$ enriched ocean. Nat Geosci 2020, 13(3): 243-248.

13. Korenaga J, Planavsky NJ, Evans DA. Global water cycle and the coevolution of the Earth's interior and surface environment. Philosophical Transactions of the Royal Society A: Mathematical, Physical and Engineering Sciences 2017, 375(2094): 20150393.

14. Ravindran A, Mezger K, Balakrishnan S, Kooijman E, Schmitt M, Berndt J. Initial ${ }^{87} \mathrm{Sr} /{ }^{86} \mathrm{Sr}$ as a sensitive tracer of Archaean crust-mantle evolution: constraints from igneous and sedimentary rocks in the western Dharwar Craton, India. Precambrian Res 2019: 105523.

15. Satkoski AM, Lowe DR, Beard BL, Coleman ML, Johnson CM. A high continental weathering flux into Paleoarchean seawater revealed by strontium isotope analysis of $3.26 \mathrm{Ga}$ barite. Earth Planet Sci Lett 2016, 454: 28-35.

16. Greber ND, Dauphas N, Bekker A, Ptáček MP, Bindeman IN, Hofmann A. Titanium isotopic evidence for felsic crust and plate tectonics 3.5 billion years ago. Science 2017, 357(6357): 1271-1274. 
17. Garçon M, Carlson RW, Shirey SB, Arndt NT, Horan MF, Mock TD. Erosion of Archean continents: The Sm-Nd and Lu-Hf isotopic record of Barberton sedimentary rocks. Geochim Cosmochim Acta 2017, 206: 216-235.

18. Nebel-Jacobsen Y, Nebel O, Wille M, Cawood PA. A non-zircon Hf isotope record in Archean black shales from the Pilbara craton confirms changing crustal dynamics ca. $3 \mathrm{Ga}$ ago. Scientific Reports 2018, 8(1): 922.

19. Roerdink DL, Mason PRD, Whitehouse MJ, Brouwer FM. Reworking of atmospheric sulfur in a Paleoarchean hydrothermal system at Londozi, Barberton Greenstone Belt, Swaziland. Precambrian Res 2016, 280: 195-204.

20. Kohler EA, Anhaeusser CR. Geology and geodynamic setting of Archaean silicic metavolcaniclastic rocks of the Bien Venue Formation, Fig Tree Group, northeast Barberton greenstone belt, South Africa. Precambrian Res 2002, 116: 199-235.

21. Reimer TO. Archean sedimentary baryte deposits of the Swaziland Supergroup (Barberton Mountain Land, South Africa). Precambrian Res 1980, 12(1-4): 393-410.

22. Buick R, Dunlop JSR. Evaporitic sediments of Early Archaean age from the Warrawoona Group, North Pole, Western Australia. Sedimentology 1990, 37(2): 247-277.

23. Heinrichs TK, Reimer T. A sedimentary barite deposit from the Archean Fig Tree Group of the Barberton Mountain Land (South Africa). Econ Geo/ 1977, 72(8): 1426-1441.

24. Deb M, Hoefs J, Bauman A. Isotopic composition of two Precambrian stratiform barite deposits from the Indian shield. Geochim Cosmochim Acta 1991, 55(1): 303-308.

25. Lowe DR, Drabon N, Byerly GR. Crustal fracturing, unconformities, and barite deposition, 3.26-3.23 Ga, Barberton Greenstone Belt, South Africa. Precambrian Res 2019, 327: 34-46.

26. Bao H, Rumble lii D, Lowe DR. The five stable isotope compositions of Fig Tree barites: Implications on sulfur cycle in ca. 3.2 Ga oceans. Geochim Cosmochim Acta 2007, 71(20): 4868-4879.

27. Roerdink DL, Mason PRD, Farquhar J, Reimer T. Multiple sulfur isotopes in Paleoarchean barites identify an important role for microbial sulfate reduction in the early marine environment. Earth Planet Sci Lett 2012, 331-332: 177-186.

28. Ueno Y, Ono S, Rumble D, Maruyama S. Quadruple sulfur isotope analysis of ca. 3.5 Ga Dresser Formation: New evidence for microbial sulfate reduction in the early Archean. Geochim Cosmochim Acta 2008, 72: 5675-5691.

29. Muller É, Philippot P, Rollion-Bard C, Cartigny P, Assayag N, Marin-Carbonne J, et al. Primary sulfur isotope signatures preserved in high-grade Archean barite deposits of the Sargur Group, Dharwar Craton, India. Precambrian Res 2017, 295(Supplement C): 38-47.

30. Muller E, Philippot P, Rollion-Bard C, Cartigny P. Multiple sulfur-isotope signatures in Archean sulfates and their implications for the chemistry and dynamics of the early atmosphere. Proceedings of the National Academy of Sciences 2016, xx.

31. Nijman W, de Bruijne KH, Valkering ME. Growth fault control of Early Archaean cherts, barite mounds and chert-barite veins, North Pole Dome, Eastern Pilbara, Western Australia. Precambrian Res 1999, 
95: $247-274$.

32. Hofmann A, Harris C. Silica alteration zones in the Barberton greenstone belt: A window into subseafloor processes 3.5-3.3 Ga ago. Chem Geol 2008, 257: 221-239.

33. Shikazono N. Precipitation mechanisms of barite in sulfate-sulfide deposits in back-arc basins. Geochim Cosmochim Acta 1994, 58(10): 2203-2213.

34. Jamieson JW, Hannington MD, Tivey MK, Hansteen T, Williamson NM-B, Stewart M, et al. Precipitation and growth of barite within hydrothermal vent deposits from the Endeavour Segment, Juan de Fuca Ridge. Geochim Cosmochim Acta 2016, 173: 64-85.I

35. Hanor JS. Barite-Celestine Geochemistry and Environments of Formation. In: Alpers CN, Jambor JL, Nordstrom DK (eds). Reviews in Mineralogy and Geochemistry: Sulfate minerals. Crystallography, Geochemistry and Environmental Significance. , vol. 40. Mineralogical Society of America: Washington, D.C., 2000.

36. Van Kranendonk MJ, Pirajno F. Geochemistry of metabasalts and hydrothermal alteration zones associated with c. $3.45 \mathrm{Ga}$ chert and barite deposits: implications for the geological setting of the Warrawoona Group, Pilbara Craton, Australia. Geochem Explor Environ Anal 2004, 4(3): 253-278.

37. Tice MM, Bostick BC, Lowe DR. Thermal history of the 3.5-3.2 Ga Onverwacht and Fig Tree Groups, Barberton greenstone belt, South Africa, inferred by Raman microspectroscopy of carbonaceous material. Geology 2004, 32(1): 37-40.

38. Lana C, Kisters AFM, Stevens G. Exhumation of Mesoarchean TTG gneisses from the middle crust: Insights from the Steynsdorp core complex, Barberton granitoid-greenstone terrain, South Africa. Geol Soc Am Bull 2010, 122: 183-197.

39. Hokada T, Horie K, Satish-Kumar M, Ueno Y, Nasheeth A, Mishima K, et al. An appraisal of Archaean supracrustal sequences in Chitradurga schist belt, western Dharwar Craton, southern India.

Precambrian Res 2013, 227: 99-119.

40. Montinaro A, Strauss H, Mason PRD, Roerdink D, Münker C, Schwarz-Schampera U, et al. Paleoarchean sulfur cycling: Multiple sulfur isotope constraints from the Barberton Greenstone Belt, South Africa. Precambrian Res 2015, 267: 311-322.

41. Paris G, Fischer WW, Johnson JE, Webb SM, Present TM, Sessions AL, et al. Deposition of sulfate aerosols with positive $\Delta^{33} S$ in the Neoarchean. Geochim Cosmochim Acta 2020.

42. Nabhan S, Marin-Carbonne J, Mason PR, Heubeck C. In situ S-isotope compositions of sulfate and sulfide from the 3.2 Ga Moodies Group, South Africa: A record of oxidative sulfur cycling. Geobiology 2020.

43. Chiba $\mathrm{H}$, Sakai H. Oxygen isotope exchange rate between dissolved sulfate and water at hydrothermal temperatures. Geochim Cosmochim Acta 1985, 49(4): 993-1000.

44. Wilckens FK, Reeves EP, Bach W, Seewald JS, Kasemann SA. Application of B, Mg, Li, and Sr Isotopes in Acid-Sulfate Vent Fluids and Volcanic Rocks as Tracers for Fluid-Rock Interaction in Back-Arc Hydrothermal Systems. Geochem Geophys Geosyst 2019, 20(12): 5849-5866. 
45. James RH, Allen DE, Seyfried Jr W. An experimental study of alteration of oceanic crust and terrigenous sediments at moderate temperatures (51 to $350 \mathrm{C}$ ): Insights as to chemical processes in near-shore ridge-flank hydrothermal systems. Geochim Cosmochim Acta 2003, 67(4): 681-691.

46. Farquhar J, Bao H, Thiemens M. Atmospheric Influence of Earth's Earliest Sulfur Cycle. Science 2000, 289(5480): 756-758.

47. Hans $\mathrm{U}$, Kleine T, Bourdon B. Rb-Sr chronology of volatile depletion in differentiated protoplanets: BABI, ADOR and ALL revisited. Earth Planet Sci Lett 2013, 374: 204-214.

48. Taylor SR, McLennan SM. The continental crust: its composition and evolution. 1985.

49. Salters VJM, Stracke A. Composition of the depleted mantle. Geochem Geophys Geosyst 2004, 5(5).

50. McCulloch MT. Primitive from an Archean barite and conjecture on the Earth's age and origin. Earth Planet Sci Lett 1994, 126(1-3): 1-13.

51. Blake RE, Chang SJ, Lepland A. Phosphate oxygen isotopic evidence for a temperate and biologically active Archaean ocean. Nature 2010, 464(7291): 1029-1032.

52. Marty B, Avice G, Bekaert DV, Broadley MW. Salinity of the Archaean oceans from analysis of fluid inclusions in quartz. CR Geosci 2018, 350(4): 154-163.

53. Blount CW. Barite solubilities and thermodynamic quantities up to 300 degrees $\mathrm{C}$ and 1400 bars. Am Minera/ 1977, 62(9-10): 942-957.

54. Crowe SA, Paris G, Katsev S, Jones C, Kim S-T, Zerkle AL, et al. Sulfate was a trace constituent of Archean seawater. Science 2014, 346(6210): 735-739.

55. Havig JR, Hamilton TL, Bachan A, Kump LR. Sulfur and carbon isotopic evidence for metabolic pathway evolution and a four-stepped Earth system progression across the Archean and Paleoproterozoic. Earth-Science Reviews 2017, 174: 1-21.

56. Satkoski AM, Fralick P, Beard BL, Johnson CM. Initiation of modern-style plate tectonics recorded in Mesoarchean marine chemical sediments. Geochim Cosmochim Acta 2017, 209: 216-232.

57. Lowe DR. Restricted shallow-water sedimentation of Early Archean stromatolitic and evaporitic strata of the Strelley Pool Chert, Pilbara Block, Western Australia. Precambrian Res 1983, 19(3): 239-283.

58. Fedo CM, Myers JS, Appel PWU. Depositional setting and paleogeographic implications of earth's oldest supracrustal rocks, the >3.7 Ga Isua Greenstone belt, West Greenland. Sediment Geol 2001, 141-142: 61-77.

59. Buick R, Thornett JR, McNaughton NJ, Smith JB, Barley ME, Savage M. Record of emergent continental crust $\sim 3.5$ billion years ago in the Pilbara craton of Australia. Nature 1995, 375(6532): 574-577.

60. Hoffmann JE, Zhang C, Moyen J-F, Nagel TJ. The Formation of Tonalites-TrondjhemiteGranodiorites in Early Continental Crust. In: Van Kranendonk MJ, Bennett VC, Hoffmann JE (eds). Earth's Oldest Rocks (Second Edition). Elsevier, 2019, pp 133-168.

61. Tang M, Chen K, Rudnick RL. Archean upper crust transition from mafic to felsic marks the onset of plate tectonics. Science 2016, 351(6271): 372-375. 
62. Veizer J, Ala D, Azmy K, Bruckschen P, Buhl D, Bruhn F, et al. ${ }^{87} \mathrm{Sr} /{ }^{86} \mathrm{Sr}, \delta^{13} \mathrm{C}$ and $\delta^{18} \mathrm{O}$ evolution of Phanerozoic seawater. Chem Geol 1999, 161(1): 59-88.

63. Flament N, Coltice N, Rey PF. The evolution of the $87 \mathrm{Sr} / 86 \mathrm{Sr}$ of marine carbonates does not constrain continental growth. Precambrian Res 2013, 229: 177-188.

64. Hao J, Knoll AH, Huang F, Hazen RM, Daniel I. Cycling phosphorus on the Archean Earth: Part I. Continental weathering and riverine transport of phosphorus. Geochim Cosmochim Acta 2020, 273: 70-84.

65. Prokoph A, Shields GA, Veizer J. Compilation and time-series analysis of a marine carbonate $\delta 180$, $\delta 13 \mathrm{C}, 87 \mathrm{Sr} / 86 \mathrm{Sr}$ and $\delta 34 \mathrm{~S}$ database through Earth history. Earth-Science Reviews 2008, 87(3): 113133.

66. Canfield DE, Farquhar J. Animal evolution, bioturbation, and the sulfate concentration of the oceans. Proc Nat Acad Sci USA 2009, 106(20): 8123-8127.

\section{Figures}



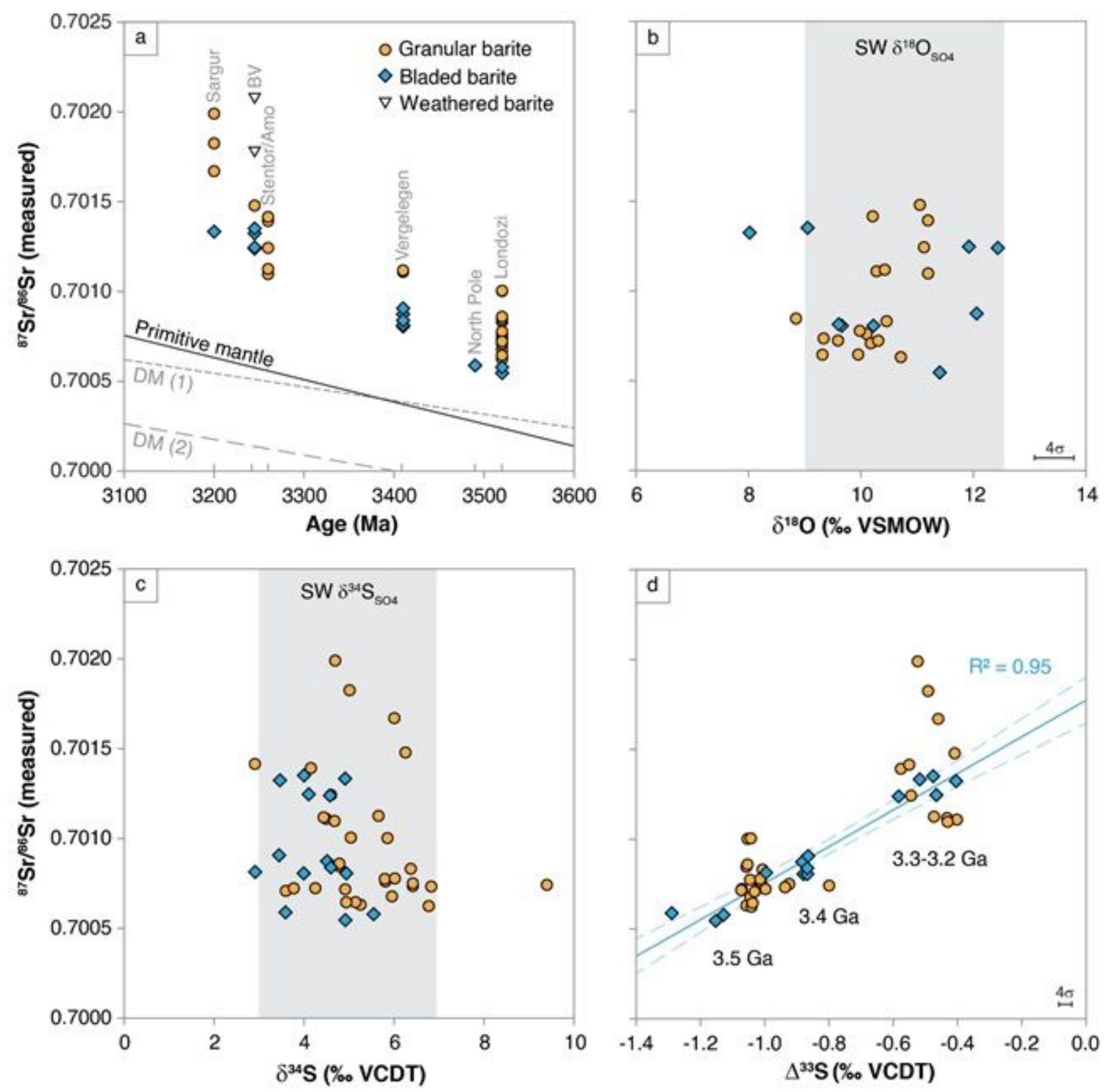

Figure 1

$\mathrm{Sr}, \mathrm{S}$ and $\mathrm{O}$ isotopic compositions of Paleoarchean stratiform barite. (a) Measured 87Sr/86Sr in bladed, granular and weathered barite versus age, with the primitive and depleted mantle curves shown for comparison (see text for calculations). Deposit names are indicated, with BV = Barite Valley. (b) Measured $87 \mathrm{Sr} / 86 \mathrm{Sr}$ in bladed and granular barite versus $\delta 180$ (this study, 40 ), with the published range of seawater sulfate $\delta 18015,26$. (c) Measured $87 \mathrm{Sr} / 86 \mathrm{Sr}$ in bladed and granular barite versus $\delta 34 \mathrm{~S}$ (this study, 27), with the published range of seawater sulfate $\delta 34 \mathrm{~S} 26,41,42,66$. (d) Measured 87Sr/86Sr in bladed and granular barite versus $₫ 33 \mathrm{~S}$ (this study, 27), showing the linear trend (with $95 \%$ confidence intervals) defined by the bladed barite samples reflecting temporal evolution of seawater. Error bars are indicated when errors are larger than the symbols. 

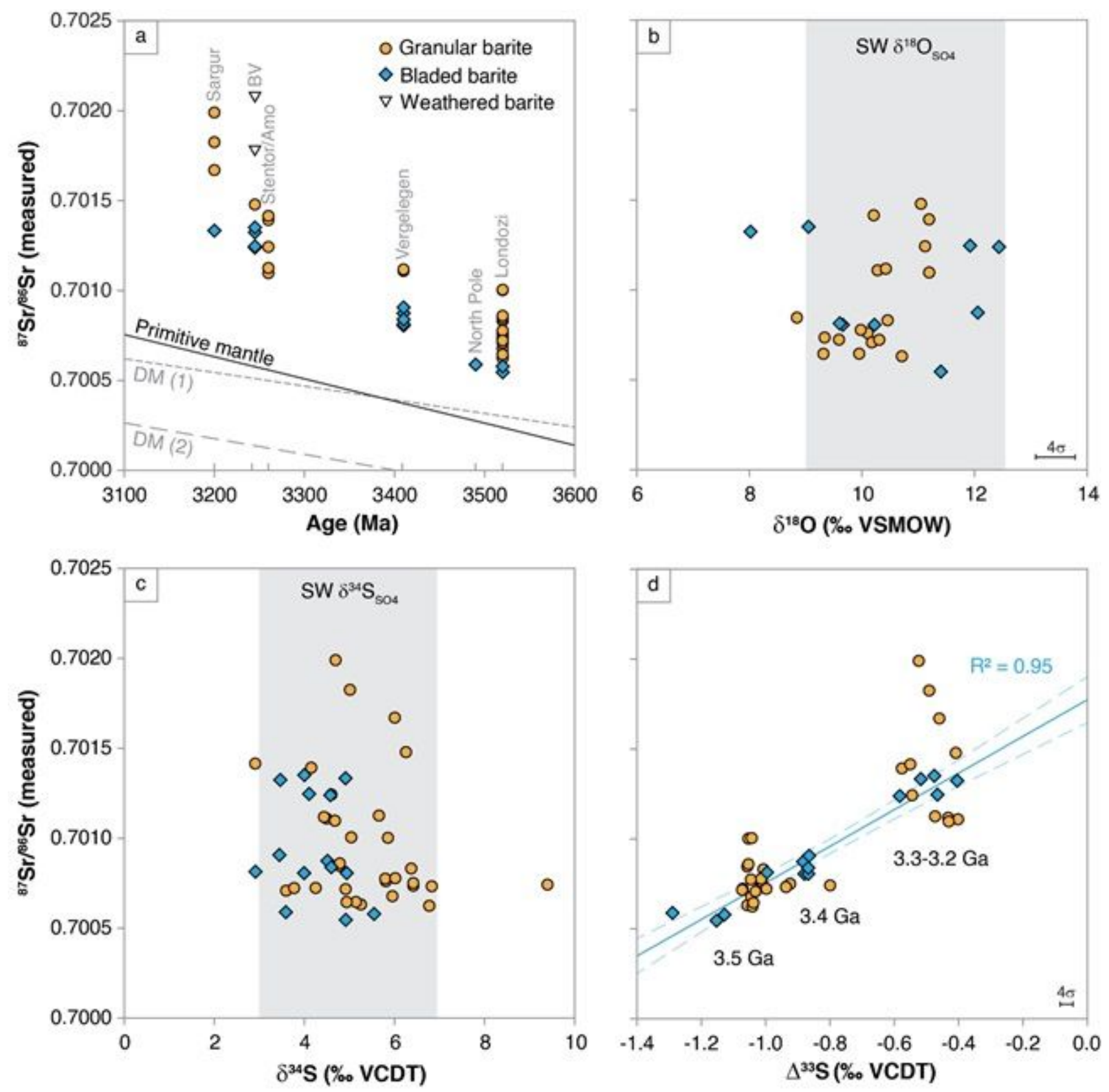

\section{Figure 1}

$\mathrm{Sr}, \mathrm{S}$ and $\mathrm{O}$ isotopic compositions of Paleoarchean stratiform barite. (a) Measured $87 \mathrm{Sr} / 86 \mathrm{Sr}$ in bladed, granular and weathered barite versus age, with the primitive and depleted mantle curves shown for comparison (see text for calculations). Deposit names are indicated, with BV = Barite Valley. (b) Measured $87 \mathrm{Sr} / 86 \mathrm{Sr}$ in bladed and granular barite versus $\delta 180$ (this study, 40 ), with the published range of seawater sulfate $\delta 18015,26$. (c) Measured $87 \mathrm{Sr} / 86 \mathrm{Sr}$ in bladed and granular barite versus $\delta 34 \mathrm{~S}$ (this study, 27), with the published range of seawater sulfate $\delta 34 \mathrm{~S} 26,41,42,66$. (d) Measured 87Sr/86Sr in bladed and granular barite versus $₫ 33 \mathrm{~S}$ (this study, 27), showing the linear trend (with $95 \%$ confidence intervals) defined by the bladed barite samples reflecting temporal evolution of seawater. Error bars are indicated when errors are larger than the symbols. 


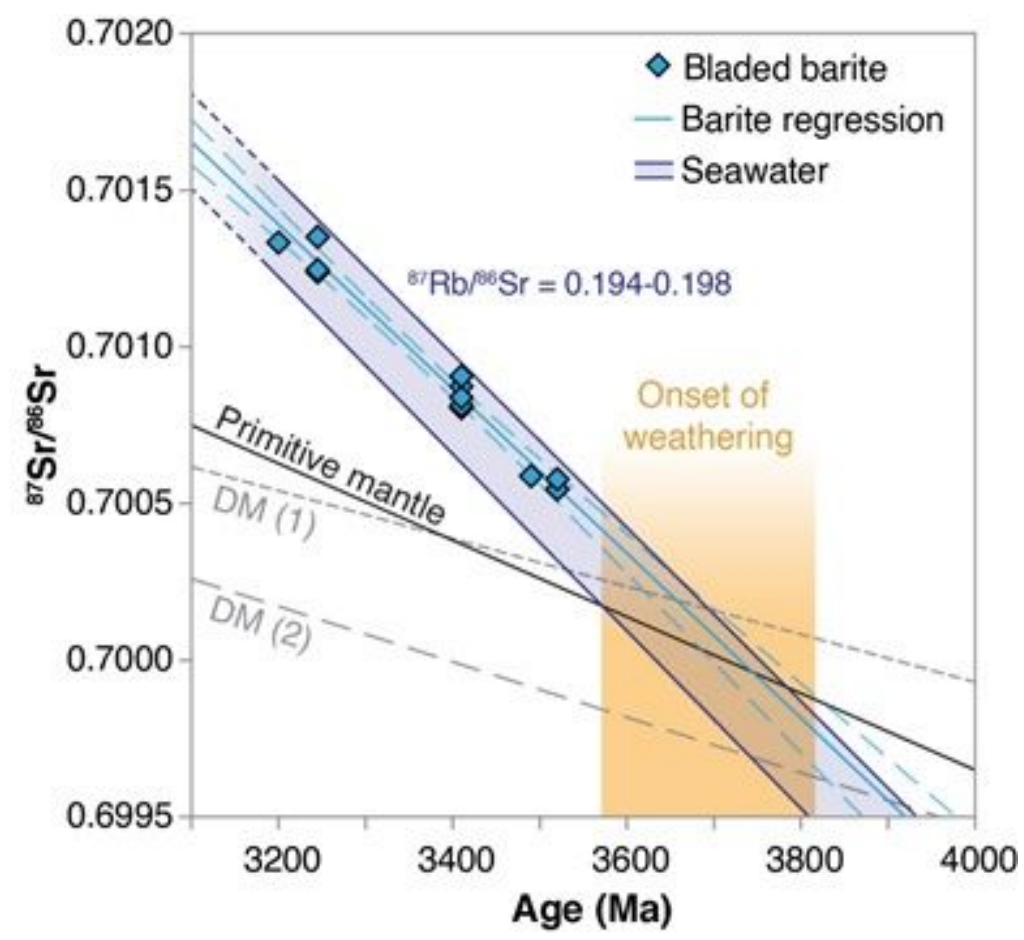

Figure 2

Measured and modelled Paleoarchean seawater curves. Sr isotope evolution trend for Paleoarchean seawater calculated from the hydrothermal mixing model and bladed barite $87 \mathrm{Sr} / 86 \mathrm{Sr}$ (dark blue lines). Also shown is the regression line for the bladed barite (light blue line with $95 \%$ confidence intervals). Primitive and depleted mantle curves are the same as those shown in Fig. 1a (see text for calculations). The onset of large scale subaerial crustal weathering is defined by the intersection of the seawater and mantle curves at $3.7 \pm 0.1 \mathrm{Ga}$.

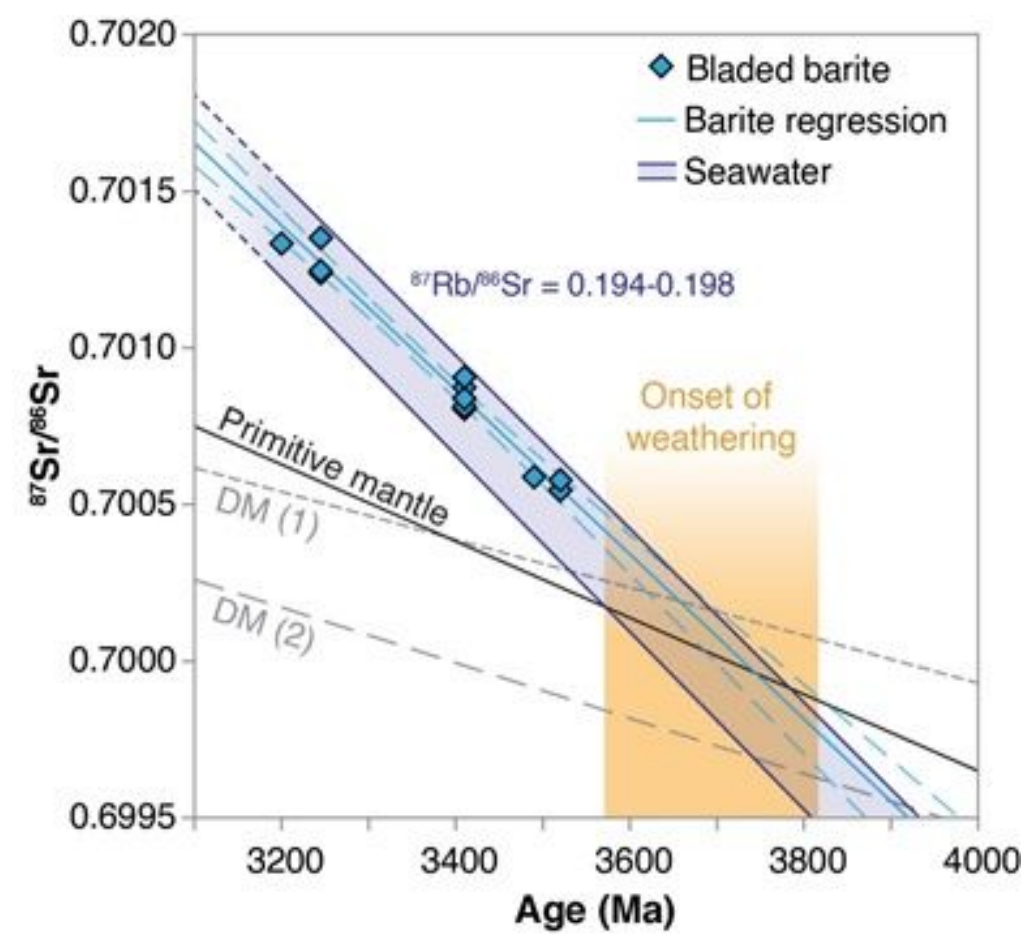

Figure 2 
Measured and modelled Paleoarchean seawater curves. Sr isotope evolution trend for Paleoarchean seawater calculated from the hydrothermal mixing model and bladed barite $87 \mathrm{Sr} / 86 \mathrm{Sr}$ (dark blue lines). Also shown is the regression line for the bladed barite (light blue line with $95 \%$ confidence intervals). Primitive and depleted mantle curves are the same as those shown in Fig. 1a (see text for calculations). The onset of large scale subaerial crustal weathering is defined by the intersection of the seawater and mantle curves at $3.7 \pm 0.1 \mathrm{Ga}$.

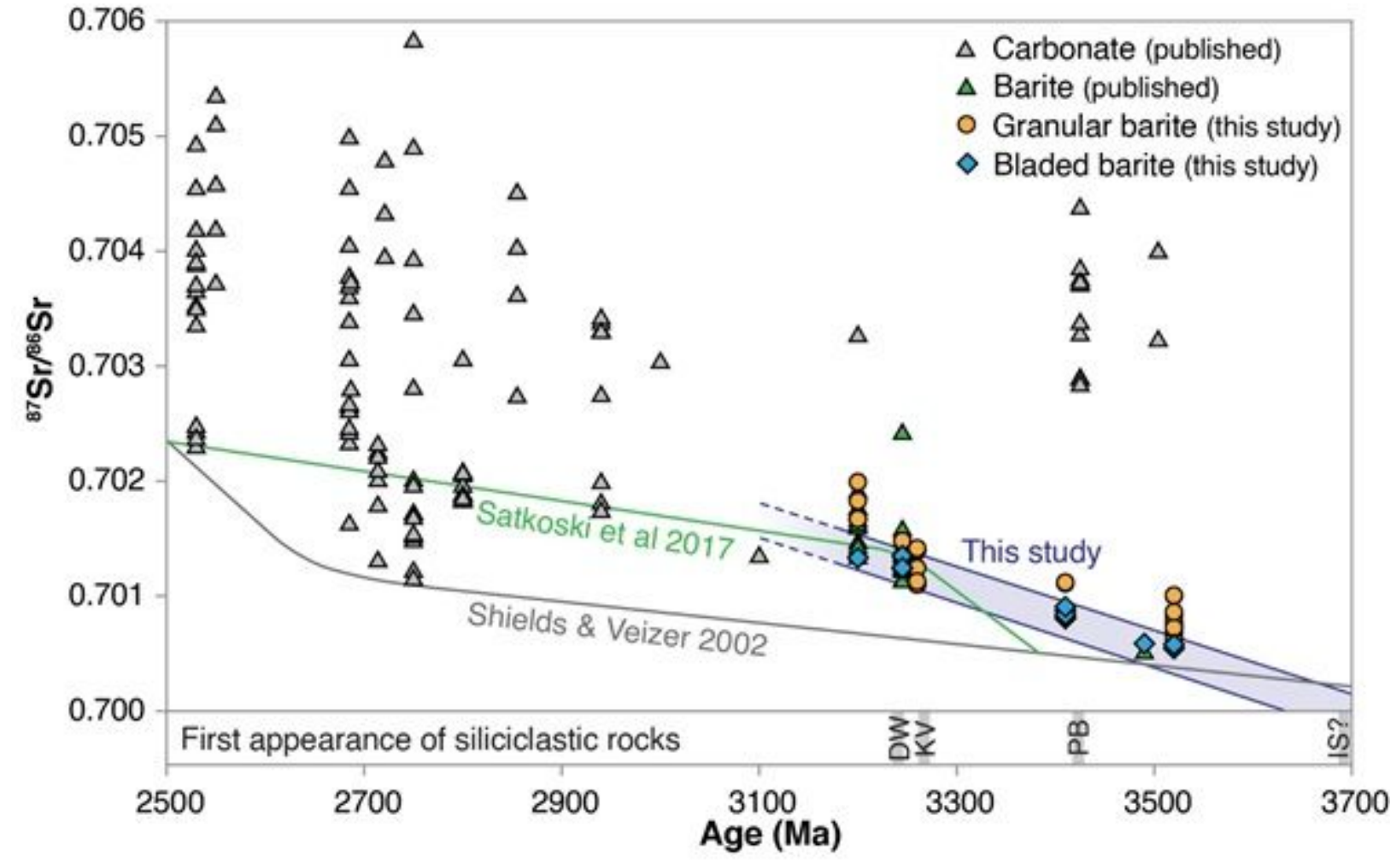

Figure 3

Compilation of Archean barite and carbonate $\mathrm{Sr}$ isotope data. Barite $87 \mathrm{Sr} / 86 \mathrm{Sr}$ from this study (blue diamonds and yellow circles), published barite $87 \mathrm{Sr} / 86 \mathrm{Sr}$ (green triangles) 14, 15, 50 and published carbonate $87 \mathrm{Sr} / 86 \mathrm{Sr}$ (grey triangles) 9, 56, 65 for the Paleoarchean, Mesoarchean and Neoarchean. Our seawater Sr isotope evolution trend is shown (dark blue lines, cf. Fig. 2) in comparison with the curve predicted by Satkoski et al.56 based on 3.2 Ga barite and 2.94-2.8 Ga carbonate (green line), and the carbonate-based mantle-dominated seawater curve by Shields and Veizer (grey line) 6 . The first appearance of siliciclastic rocks in the rock record is indicated for each craton on the lower axis, with DW = Dharwar craton, KV = Kaapvaal craton, PB = Pilbara craton and IS = Isua Greenstone Belt (see Table S6 for details and references). 


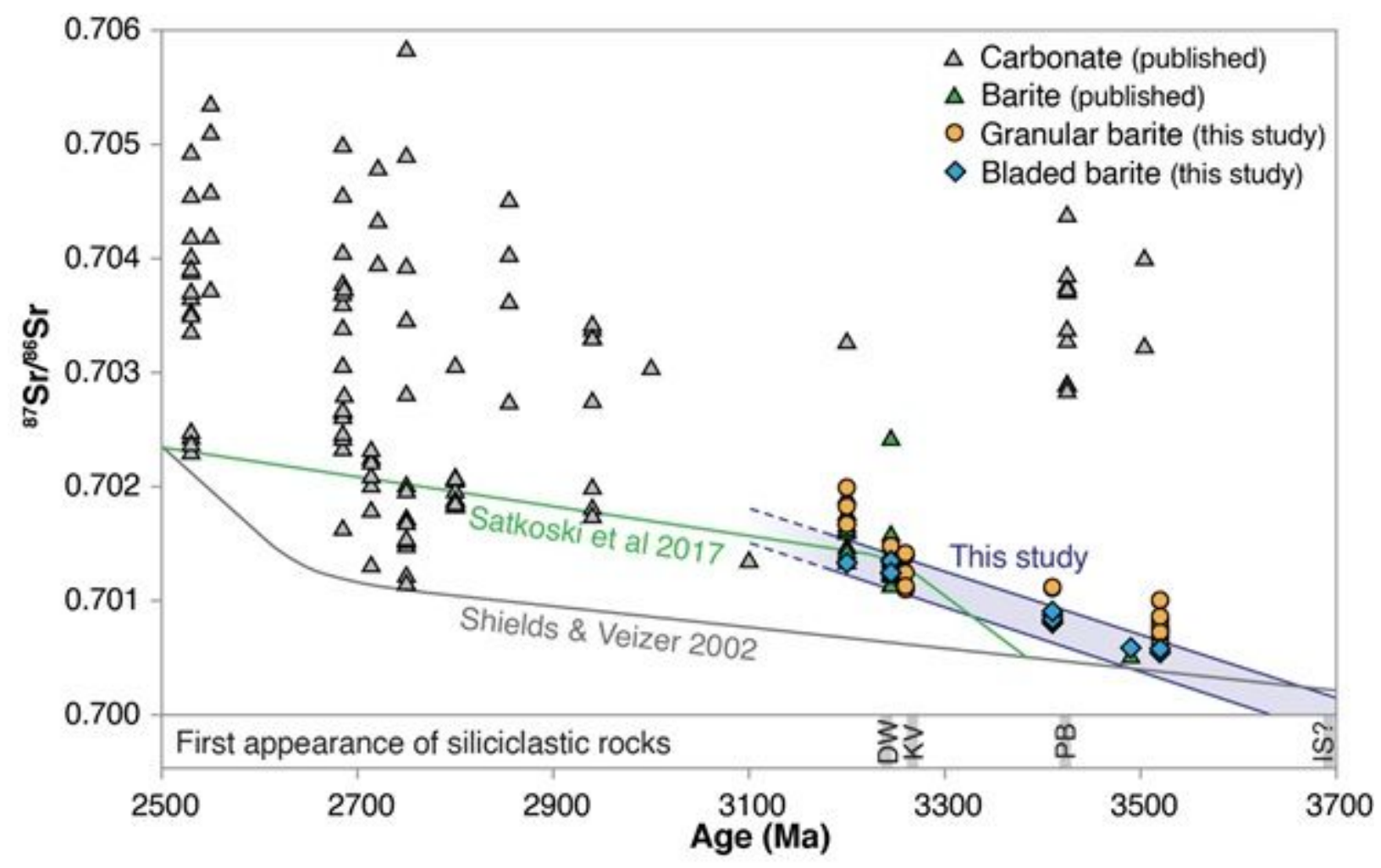

Figure 3

Compilation of Archean barite and carbonate $\mathrm{Sr}$ isotope data. Barite $87 \mathrm{Sr} / 86 \mathrm{Sr}$ from this study (blue diamonds and yellow circles), published barite $87 \mathrm{Sr} / 86 \mathrm{Sr}$ (green triangles) 14, 15, 50 and published carbonate $87 \mathrm{Sr} / 86 \mathrm{Sr}$ (grey triangles) 9, 56, 65 for the Paleoarchean, Mesoarchean and Neoarchean. Our seawater Sr isotope evolution trend is shown (dark blue lines, cf. Fig. 2) in comparison with the curve predicted by Satkoski et al.56 based on 3.2 Ga barite and 2.94-2.8 Ga carbonate (green line), and the carbonate-based mantle-dominated seawater curve by Shields and Veizer (grey line) 6 . The first appearance of siliciclastic rocks in the rock record is indicated for each craton on the lower axis, with DW = Dharwar craton, KV = Kaapvaal craton, PB = Pilbara craton and IS = Isua Greenstone Belt (see Table S6 for details and references).

\section{Supplementary Files}

This is a list of supplementary files associated with this preprint. Click to download.

- RoerdinketalSrisotopes2020SupplementaryinfoSUBMIT.docx

- RoerdinketalSrisotopes2020SupplementaryinfoSUBMIT.docx

- RoerdinketalSrisotopes2020SupplementaryTableS2SUBMIT.xIsx

- RoerdinketalSrisotopes2020SupplementaryTableS2SUBMIT.xIsx 